\title{
Framing an EU Level Regularization Mechanism: Mission Impossible?
}

\author{
Ali Bilgic*
}

\begin{abstract}
European Union Member States have so far tackled the problem of irregular migration in Europe by adopting common policies which aim to prevent irregular arrivals on the EU borders. In their EU-level policies, they have neglected regularization as an alternative EU-level policy addressing irregular migration. This represents a contrast to regularizations which are performed by many EU Member States. However, the EU Commission has gradually adopted a more positive stance about regularization. This article will discuss the principles of an EUlevel regularization scheme through the analysis of the Commission's ideas on the issue. It will be argued that, rather than adopting a common policy, the flexible set of measures, which guide Member States in formulating regularization mechanism for protection/humanitarian reasons, can be formulated at the EU level.
\end{abstract}

During the 2010 election campaign the leader of United Kingdom Liberal Democrats, Nick Clegg, suggested the regularization of irregular migrants residing in the UK. This suggestion provoked fierce criticisms claiming that 'amnesty' is not a solution to the problem of irregular migration. ${ }^{1}$ These criticisms reflect the negative public perceptions of regularization. The interesting point is that in many European Union (EU) member states, including the UK, regularization is not a very rare practice. However, member states have so far overlooked regularization at EU level as a policy for irregular migration control. This oversight constitutes a discrepancy because the EU Commission, which was opposed to regularization in the past, is now playing the role of norm entrepreneur in the emerging international regime of regularization.

This study, which is based on the author's doctoral research conducted at Aberystwyth University between 2006 and 2010, will examine regularization from the EU perspective. It will discuss the contours of a possible EU level regularization scheme built upon the norm of protection promoted by the Commission in the emerging international regime of regularization. It will be argued that a regularization mechanism for protection reasons at EU level has the potential to address key problems posed by irregular migration to member states. If this can be achieved, regularization can be a long-term and principled policy for irregular migration control.

The argument will be pursued in two sections. In the first section, it will be argued that the understanding of regularization as an 'extraordinary state-level policy' has hampered the development of a common position about the issue at EU level. Following the identification of the problem, three objectives will be pursued in the second section. First, the emerging international regime of protection will be examined. Second, the Commission will be situated in this emerging regime as a norm entrepreneur. The primary norm the Commission has promoted is the norm of protection. Third, based on this norm and on ideas developed through Commission-funded

\footnotetext{
* Bilkent University, Ankara.
} 
academic studies, the characteristics of an EU level regularization mechanism for protection reasons will be laid out. ${ }^{2}$

In a broad sense, regularization schemes 'offer those migrants who are in a country without authorization the opportunity to legalize their status' (Levinson, 2005b). Migrants without authorization are those who entered a country without documents or with forged documents and those who overstayed after their visas or other documents expired. As these descriptions illustrate, both 'authorization' and 'legalization' (only residence permit or also work permit? temporary or permanent?) are both multifaceted dimensions of regularization. Given this complexity, what type of regularization can be formulated and which group of irregular migrants can be targeted are questions waiting to be answered. This study is an attempt to answer them in the context of the EU through discussing the Commission's norm entrepreneurship. ${ }^{3}$

\section{REGULARIZATION CONONDRUM IN THE EU FACING IRREGULAR MIGRATION}

All regularization schemes target irregular migration. The Commission's framing of an 'irregular migrant' is broad enough to include those migrants who attempt to enter the EU without documents or with forged documents, migrants who reside in the EU without residence permits and overstay their visas, and rejected asylum-seekers who are tolerated by governments (Commission, 2006). The Commission's framing reveals the complexity of the meaning of irregular migration. Migrants with very different motivations become 'irregular' for various reasons (see below). Among many, voices from some EU bodies argue that the main reason for irregularity is lack of sufficient legal channels of migration, urging member states to consider new legal migration channels (Ghosh, 1998: 35; Commission, 2000; Bruggeman, 2002). ${ }^{4}$

Rather than opening new legal migration channels, member states have tackled the challenges posed by irregular migration through policies aimed to prevent irregular arrivals in the first place. However, in spite of the various policies, including militarized means for fighting irregular migration, the problem of irregular migration to the EU continues (UNODC, 2006; Fergues, 2009). Faced with such a challenge at European scale, member states need to search for alternative and more efficient ways of tackling irregular migration. In this respect, the Commission has already begun to consider regularization as an alternative policy. Although the Commission's consideration seems to run counter to the dominant migration control policies, a closer look at member states' practices suggests otherwise.

Since the 1980s, EU member states have put regularization schemes into effect (Levinson, 2005a; Papadopoulou, 2005). According to a study on regularization trends in the member states between 1996 and 2007, funded by the Commission, in 42 regularization programs from $27 \mathrm{EU}$ member states, 2.9 million irregular migrants were granted legal status out of 4.2 million applicants. Southern Mediterranean countries are at the top of the regularization programs with the highest number of migrants regularized (Baldwin-Edwards and Kraler, 2009: 31). The regularization program was announced in Belgium in July 2009.

One of the most striking facts about regularization practices in the EU is that although many member states have repeatedly operationalized regularization schemes, they have so far avoided constructing a common position about the issue at EU level. ${ }^{6}$ Given that EU member states have increasingly worked together to prevent the arrival of irregular migrants through establishing joint naval operations conducted under the supervision of FRONTEX, and through harmonizing and externalizing asylum procedures in order to prevent the abuse of the system with the cooperation of neighbouring states (Lutterbeck, 2006; Gammeltoft-Hansen, 2007; Spijkerboer, 2007; Adepoju et al., 2009), the question arises: why have they neglected regularization as a viable policy option to 
prevent irregular migration at EU level? A possible answer is that regularization at international scale is still considered to be an extraordinary policy; and that governments desire to have full decision-making power about how and when this extraordinary policy is implemented. The political baggage and risks of the policy, which will be discussed below, can discourage states from prioritizing regularization over return.

Another reason is the legal/technical difficulties of adopting a common regularization policy. What does 'regularization' mean? Which group of irregular migrants can or should be regularized? How can the policy be operationalized? The type of irregular migrants in a country, and the criteria and the bureaucratic process of regularization are different in member states (Blaschke, 2008). This is why the International Centre for Migration Policy Development (ICMPD) suggested that a 'onesize-fits-all' definition of regularization is not practical and that the EU should define flexible sets of measures which can be adjusted in accordance with the specific needs of each country (Baldwin-Edwards and Kraler, 2009). Therefore, the rest of the discussion will focus on the flexible set of measures which can be defined at EU level and guide member states in their regularization practices.

\section{PRINCIPLES FOR A REGULARIZATION MECHANISM FOR PROTECTION REASONS AT THE EU LEVEL: THE COMMISSION'S NORM ENTREPRENEURSHIP}

In this section, first, the basic characteristics of the emerging international regime of regularization will be described. Second, the discussion will move to the principle norm of regularization that the Commission promotes in this slender regime. Finally, based on this norm and ideas developed in the Commission-funded academic studies, the defining features of a regularization scheme in the EU will be discussed, along with its possible criticisms.

\section{The Emerging International Regime of Regularization}

The reluctance of states to develop rules about regularization in international law should not lead us to the conclusion that regularization is completely neglected by the various actors. Based on the decisions of particular organizations, it can be argued that there is an emerging international regime of regularization, although it is at present quite thin. One of the outspoken organizations for regularization as a solution to irregular migration problem is the Council of Europe (CoE). According to a recommendation of the Parliamentary Assembly of the Council, regularization not only helps states to regain control over the underground economy, but also 'offer[s] the possibility for safeguarding the rights of irregular migrants who are often in a particularly vulnerable situation' (CoE, 2007a). The Council of Europe manifestly favoured regularization over return in a resolution adopted in 2007(CoE, 2007b).

In parallel, the European Court of Human Rights (ECHR) has produced many decisions in relation to the rights of irregular migrants and the regularization of their stay as a matter of the protection of irregular migrants' rights (Thym, 2008). Another organization which argues for regularization is the Global Commission on International Migration (GCIM), an influential thinktank on the issue of migration. According to a report published in 2005, regularization is supported on the basis that the incoherence of the restrictive migration policies and the demand for labour leads to irregular movement. It argued that, despite possible negative effects, states should consider regularization as a viable option (GCIM, 2005).

Two characteristics of the emerging international regime of regularization can be derived from the reports, regulations, and decisions just highlighted. The first is that regularization can be a use- 
ful tool to prevent law-breaking, by registering undocumented migrants and consequently eradicating the underground economy. The rationale here is that, through regularization, states are able to regain control of certain sectors of society.

The second characteristic is that regularization can be an important tool in stopping the marginalization of irregular migrants, by registering and integrating them into society. This is crucial, not only for the protection of the human rights of irregular migrants but also because it serves the first characteristic: through integration, the threat of economic and social insecurity that irregular migration pose to the receiving communities can be decreased. The discussion below aims to reveal that the Commission can play a leading role in strengthening this international regime.

\section{The Commission's Norm Entrepreneurship in the Area of Regularization}

The Commission's approach to regularization has shifted from anti-regularization to pro-regularization, albeit with specific concerns. While it opposes collective and one-off regularization programs, which are common practice in many member states, the Commission proposes a type of regularization scheme which aims to register and integrate irregular migrants who cannot be returned for humanitarian reasons. Hence, the Commission's formulation specifically addresses those irregular migrants who came to the EU to seek protection but failed to obtain refugee status. This point needs to be clarified.

Some immigrants do not leave their countries solely because of the violation of their political rights. That is why these immigrants cannot apply for asylum and/or become refugees; because their migration is neither forced nor based on persecution in the way defined by the 1951 Refugee Convention. Refugees and asylum-seekers are an important group of immigrants involved in the contemporary forced migration phenomenon, but not the only group. Forced migrants are those "who flee or are obliged to leave their homes or places of habitual residence because of events threatening to their lives or safety' (Martin, 2000; see also Turton, 2003). These migrants do not leave countries solely because of political persecution (making them non-eligible for refugee status), but due to reasons hindering the possibility of realizing human rights in general. According to DeWind (2007: 382), 'international migrants deprived of political, social and economic rights... need and deserve international protection no less than refugees'. When these forced migrants become irregular, it does not mean that they do not need protection. The Commission's regularization perspective is based on the norm of protection targeting this specific group of forced migrants.

An important practice of the Commission in the process of formulating an EU-level set of measures about regularization has been to fund academic studies about regularization practices in member states. In 2000, the Commission contributed financially to the Odysseus Network, which was created in 1998 under the Free University of Brussels. The network published a European-wide study on regularization practices in different member states, a study which was also funded by the Commission. ${ }^{7}$ Although the report specifically focused on the legal dimension of regularization practices in eight states (France, Belgium, Germany, Greece, the United Kingdom, the Netherlands, Italy, and Spain), rather than political and practical advantages and disadvantages of the issue, the study revealed the Commission's interest in regularization (Apap et al., 2000).

In 2006, the Commission's interest led to the launch of another study whose objective was to 'constitute the basis for future discussion, including on whether there is a need for legal framework on regularization at EU level' (Commission, 2006). The report was prepared by the International Centre for Migration Policy Development (ICMPD), and was published in January 2009 (Baldwin-Edwards and Kraler, 2009). Between these two reports, the Commission's conception of regularization changed significantly. As the norm of protection has been strengthened, by adopting this norm the Commission has begun to support a specific type of regularization scheme. 
In a communication issued in 2001, the Commission explicitly made the point that regularization should not be a way of dealing with irregular migration. It manifestly stated that opening legal channels in the form of regularization for labour migration should not be a 'panacea' for irregular migration (Commission, 2001). The Commission, at the beginning, understood regularization in relation to the issue of irregular migration for economic purposes, which characterizes a large part of the problem, especially in Southern member states. Therefore, it opposed regularization as a policy tool to tackle labour shortage in certain areas of economy such as agriculture.

However, in 2003, the Commission changed its position on the issue. It started to evaluate irregularity as a problem of the protection of irregular migrants and to conceive regularization as a would-be solution to this problem. The Commission still favoured return over regularization, as stated in the communication; however it also stated that 'in a considerable number of cases it is not possible to implement such a policy for legal, humanitarian or practical reasons' (Commission, 2003). For the Commission, the objective of ensuring social cohesion and providing protection to those irregular migrants who cannot be returned to their countries for humanitarian reasons should also be given due importance. This means that the Commission has started to treat regularization as a viable and necessary political option, to ensure better integration of irregular migrants by protecting and promoting their rights. This understanding has increasingly dominated the Commission's position.

In 2004, the Commission issued another communication. In this communication, the Commission understood regularization solely as a policy of providing protection to people in need. It implicitly celebrated government policies which, through regularization of those irregular migrants who do not meet the criteria for obtaining refugee status, 'attempt to bring such migrants into society rather than leaving them on the margins, subject to exploitation' (Commission, 2004). The Commission called this 'humanitarian or protection regularizations aimed at granting a right of residence to specific categories of persons who are not eligible to claim international protection' (Commission, 2004). The Commission's conception of regularization as a way of protection is crucial. This is because the Commission, for the second time, favoured regularization not only as a way of reducing the number of irregular migrants in the EU, but also an instrument for the protection of irregular migrants.

However, it has not so far been clarified what the Commission means by regularization. The only communication which manifestly points out what kind of regularization the Commission favours was issued in 2008. It was stated that the Commission is in favour of individual-based or case-bycase regularizations, not mass regularizations that can be perceived as 'general amnesty' (Commission, 2008). In addition, as was shown above, the Commission favours regularization only for certain group of irregular migrants. These positions are in parallel with the results of the 2009 Report by the ICMPD.

As stated earlier, regularization has not been formulated in international law. Although there are some regulations and decisions recently adopted by a very limited number of international bodies, the international regime of regularization is still very weak and far from being a structural factor which could guide or shape states' ideas about and practices of regularization. This is mainly because regularization is considered to be an issue of domestic politics, where states decide when and how they operationalize this 'extraordinary' measure against irregular migration. The discussion above about the Commission's ideas on regularization leads to the point that this traditional conception can be replaced by a new one based on three main principles.

The first principle, which is adamantly argued by the Commission, is that regularization is not only a policy of eradicating the stock of irregular migrants in a country, but a policy of integration by protecting and promoting the rights of irregular migrants. The second principle is that collective and one-off regularizations do not address the problem of irregular migration. Regularization schemes should be more principled, institutionalized, and on a case-by-case basis. Finally, in relation to the first two principles, regularization should directly and specifically address the irregular 
migrants who cannot be returned to their countries for humanitarian and/or protection reasons. In other words, regularization should be an institutionalized mechanism which aims to integrate the new irregular 'forced migrants' into the receiving society by not leaving them on the margins of the community and open to exploitation. The Commission's support of this type of regularization can be a new norm which fuels and strengthens the emerging international regime of regularization.

In the following section, based on the Commission's ideas and the Commission-funded academic studies, the principles of a regularization mechanism for protection reasons at the EU level will be discussed.

\section{Principles of EU Level Regularization Mechanism and Its Possible Criticisms}

The first Commission-funded study conceptualized regularization as 'the granting, on the part of the State, of a residence permit to a person of foreign nationality residing irregularly in its territory' (Apap et. al., 2000: 263). The authors defined two groups of irregular migrants who can be included in a regularization scheme. The first group are those who are not entitled to a residence permit because the legal regulations applicable to aliens do not cover these migrants. This group includes irregular migrants who cannot be returned to their countries for humanitarian reasons, but, at the same time, cannot be granted refugee status. This group of migrants may apply for asylum, but the likelihood of obtaining refugee status is very low, as the 1951 Refugee Convention does not cover these contemporary forced migrants (see above).

The second group of irregular migrants concerns those who formally had a permit by virtue of law, which is no longer in effect due to changes in migration laws. The Sans Papiers in France are the perfect exemplars of this group of irregular migrants. In March 1996, dozens of asylum-seekers (and some immigrants with a work permit) in France were made 'illegal' due to legislative changes. The Sans-Papiers ('without papers') invaded a church in Paris and this triggered a promigrant civil society movement across Europe (see McNevin, 2006). The regularization scheme promoted by the Commission's study supported aims to protect the rights of immigrants 'without papers'.

Based on the case studies of eight European countries, the authors create a typology for regularization. According to their study, there are five different forms of regularization:

a Permanent versus One-Off Regularizations: In permanent regularizations, the date on which an irregular immigrant entered the country does not constitute a criterion for regularization. Newly arrived migrants can apply for regularization. In contrast, one-off regularizations do not target newly-arrived migrants. The applicants should spend certain amount of time in the country. The $\mathrm{UK}$, for example, offers regularization for those who have resided in the country for 14 years; the 1986 regularization in the USA accepted 5-year long residency.

b Individual versus Collective Regularizations: While the former regularizes on a case-by-case basis, the latter can be identified as mass regularization.

c Fait-Accompli versus Protection Regularizations: This distinction is crucial for the purposes of the present article. Fait-accompli regularizations grant residence permits to irregular migrants who de facto have lived in a country for a specific period of time. The aim of the regularization is to transform the de facto situation into de jure. Its objective is simply to eradicate the stock of irregular migrants in society. In contrast, regularization for protection reasons is more principled. It targets individuals who cannot be expelled, but are ineligible to obtain protection under the framework of the 1951 Refugee Convention. The Commission strongly supports regularization for protection reasons.

d Expedience versus Obligation Regularizations: Expedience regularization is decided by states based on the needs of the receiving communities. Obligation regularization occurs when a higher 
body - for example, the European Court of Human Rights - demands states to regularize the status of certain irregular migrants.

e Informal versus Organized Regularizations: Informal regularization is individual-oriented. If an irregular immigrant applies to the authorities to regularize his/her status, his/her status is decided individually. However, if the number of applications increases, it may lead to an organized regularization campaign (Apap et al., 2000: 266-271).

The common element in all regularization practices is the adoption of criteria for application. Papadopoulou (2005: 5) defined eight criteria: residence for a particular period of time, labour contract, evidence of integration efforts, contribution to the social insurance fund, family ties, need for protection, health reasons, and nationality-based quota. Each regularization program uses different criteria. For example, the 1986 'amnesty' in the USA and many other regularization programs used the criterion of residence for a certain period of time (Baker, 1990: 9). The 1998 regularization in Greece and the 2005 regularization in Spain invoked employment criteria (Papantoniou-Grangouli and Leventi, 2000: 951; Arango and Jachimowicz, 2005). In 1999, Belgium performed regularization for humanitarian protection for failed asylum applicants who could not be returned to their countries, and for irregular migrants who suffered from serious illnesses (Levinson, 2005b). In short, regularization is performed for various reasons in different ways. As it is formulated based on the needs of the country, a strict definition of regularization does not appeal to states. That is why it is important to define regularization at the European level as widely and flexibly as possible.

The conception of regularization developed by the second Commission-funded report is more detailed. Regularization, according to the study, is 'any state procedure by which third country nationals who are irregularly residing, or who are otherwise in breach of national migration rules, in their current country of residence are granted a legal status'. Their primary distinction in the conceptualization of regularization is between 'regularization program' and 'regularization mechanism'. The regularization program is one-off, continues for a limited period of time, and targets specific groups of aliens. The program is not a dimension of the regular migration policy. In contrast, the regularization mechanism is:

any procedure other than a specific regularisation program by which the state can grant legal status to illegally present third country nationals residing on its territory. In contrast to regularisation programs, mechanisms typically involve 'earned' legalisation (e.g. by virtue of long-term residence), or humanitarian considerations (e.g. non-deportable rejected asylum-seekers, health condition, family ties etc.), and are likely to be longer-term policies. (Baldwin-Edwards and Kraler, 2009: 9).

The most important difference between the program and mechanism is that the latter is a part of regular migration policy. Unlike the program, the mechanism is not one-off and establishes a permanent system through which irregular migrants with humanitarian considerations can be regularized. The Commission, as shown above, clearly stated that it is against one-off and mass regularization. Instead, the regularization system should focus on irregular migrants who cannot be returned for humanitarian reasons. Considering these, the Commission's idea is in parallel with a regularization mechanism for protection reasons. ${ }^{8}$

The idea supported by the Commission-funded study is that if repatriation cannot be an option for humanitarian reasons, states need a more institutionalized mechanism, rather than a collective or one-off program, to have these irregular migrants registered and integrated into the host community. The report, like the Commission, is in favour of regularization mechanisms which can correct the deficiencies in domestic and international legal systems. It states that regularization mechanisms 
'reflect the need for complementary, corrective instruments which allow states to respond to particular situations in a flexible manner' (Baldwin-Edwards and Kraler, 2009: 107).

Although the main principles, which will be presented below, can be formulated at the EU level, the regularization mechanism for protection reasons can be put into effect based on the specificities of the irregular immigrant population in each member state. In other words, based on the principles formulated at EU level, each member state can formulate its own regularization mechanism. This is a crucial aspect of the policy because the characteristics of irregular migrants who cannot be returned are varied in different member states. For instance, while some group of migrants might be escaping from generalized violence, others might be fleeing from extreme poverty and others from environmental degradation. As long as the norm of protection is upheld, a member state can decide what type of irregular migrants can be regularized and how many of them can be efficiently integrated.

Unlike the general regularization practices in member states, this type of regularization is not an 'amnesty'. It is a principled policy for the prevention of irregular migration by opening a new legal channel that can appeal to those irregular migrants who seek protection in the EU. However, this type of regularization can be a target of specific anti-regularization arguments.

It is commonly argued that regularization, by rewarding those who violate laws, attracts more irregular migrants who use irregular ways to enter countries with the hope of another regularization program. However, this argument lacks any statistical proof and systematic analysis (Levinson, 2005a: 9). It is more a political argument used to manipulate public concern about irregular migration. For example, in Italy, after each regularization program, the number of irregular migrants reached the pre-regularization level. Regularization can be a motivation for some migrants to use irregular methods. However, it is not accurate to infer from this example a direct causal link between regularization and irregular migration, because such an inference reduces the numerous reasons for irregular migration to a regularization program. These reasons include lack of legal migration channels (as the Commission states), demand for irregular labour, income differences between the countries of emigration and immigration, expensiveness of legal channels, and availability of smuggling networks (see Ghosh, 1998, especially Chapter 2). In relation to the Italian case just mentioned, the Organization for Economic Co-operation Development (OECD) concluded in 2000 that the main reason for the increased number of irregular migrants in Italy is not regularization programs, but the high demand for irregular labour force in the country (OECD, 2000: 64).

This argument also neglects the role of strict border controls following the increase of irregular migration. As the legal channels of seeking protection in the EU have significantly decreased and become more expensive, more new forced migrants used irregular migration as the only way to achieve protection (Morrison and Crosland, 2001: 25-27). In other words, in addition to regularization, the formulation of new legal migration channels is vital to fight irregular migration.

Another counter-argument against the regularization mechanism concerns the political ramifications in domestic politics. Where the issue of migration is highly politicized, particular political parties and a considerable part of public opinion would resist such a scheme. Some political parties (backed by certain sectors of the media) create the image of 'sieve Europe' where irregular migrants can enter and live freely without any type of intervention by the authorities. This leads to the fear of 'irregular immigrant invasion' in certain sectors of society (Bigo, 2004: 76). In member states where this fear dominates the political arena, the incumbent governments can refrain from initiating the policy of regularization.

Decision-makers, who consider regularization as a viable political choice, can cope with these problems by prioritizing three points. The first point can be that a regularization mechanism does not aim to grant a residence permit to all applicants. This is not a 'general amnesty'. Rather, it targets specific groups of irregular migrants who cannot be returned to their countries for protection reasons. Secondly, the decision to regularize the applicants still lies with the individual state. A regularization mechanism would let irregular migrants declare themselves to the authorities and, if they 
are seeking protection, make their case; but the decision to grant residence permit is reserved for the state. Thus, irregular migration can be controlled and restricted. The final point is that a regularization mechanism does not replace the existing irregular migration policies, but is an alternative way of tackling a specific type of irregular migration.

From the perspective of the EU member states, regularization can address the concerns about irregular migration and irregular migrant population in member states. The information obtained through regularization programs can be used to draw a picture of irregular migration (Papadopoulou, 2005: 14). As a result, not only is a certain group of irregular migrants registered, but member states will be able to obtain more accurate information about the features of irregular migrant population in respective countries. This can be useful way of tackling the uncertainty that irregular migration poses to the host societies. States can regain control of migration, and therefore, ease public fears about irregular migration.

Specifically, in relation to irregular migrants who cannot be returned for protection reasons, as discussed above, a regularization mechanism can be a correcting tool of deficient domestic and international legal systems. Today in the EU member states, many asylum applications are rejected; and the rejected asylum applicants become irregular, not because they do not need a certain level of protection, but because of the narrowness of the legal systems. Like subsidiary protection or temporary protection schemes, which are other examples of corrective mechanisms, regularization can be defined as a European-level corrective mechanism for those who need protection. Based on the discussion above, it is possible to define four main principles of an EU level regularization mechanism for protection reasons:

a Regularization with opportunities for legal migration: The common agreement of the studies discussed above is that regularization cannot be the solution to irregular migration. As the Italian example suggests, the number of irregular migrants could easily increase after regularization. This means that regularization with tighter border controls does not produce solutions. In a report prepared by the Migration Policy Institute (MPI), it is suggested that border controls without legal opportunities for migration are a contributory factor to irregular migration (Papademetriou, 2005). As a solution to this problem, the Commission has been working on a 'Blue Card' scheme as a legal migration opportunity to the EU. ${ }^{9}$ Irregular migration can be effectively addressed via regularization and legal migration opportunities.

b Regularization as an individual-oriented process: As suggested in the report of the ICMPD, regularization should not be collective, mass and de facto. Applications should be evaluated caseby-case. Case-by-case regularization enables irregular migrants, who came to the EU to seek protection, to make their case about why they came to Europe, and why they chose irregular ways of travelling and of living. Individual regularization can also ease the public fears about the perverse effects of regularization by highlighting that many irregular migrants are not in Europe to abuse asylum systems or manipulate the social security schemes.

c Regularization mechanism, not program: Mechanisms are ongoing processes of integration which depend on the cooperation between the authorities and the irregular immigrant. They are more formal and principled. In contrast, programs are massive and one-off. The regularization programs have not only proven ineffective to prevent irregular migration, but have also contributed to the creation of an image about regularization as massive 'amnesty'. As states have failed to prevent irregular migration, they should find stronger, legal, principled, and long-term ways of integration.

d Regularization for protection reasons: Regularization for protection purposes should be organized, institutionalized and rights-based. A regularization mechanism for protection reasons in member states is possible, as the Commission has already expressed its support for such a scheme. Irregular protection-seekers will be the target group of this European policy which can be a corrective mechanism of the failed protection-oriented migration policies. 


\section{CONCLUSION}

This article has argued that through the Commission's norm entrepreneurship, an EU-level regularization mechanism for protection reasons can be formulated. Based on the Commission's views and the ideas developed in Commission-funded academic studies, the principles of such a mechanism have been laid out: regularization should be based on the norm of protection; it must be a longterm mechanism, rather than a one-off program; regularization must be decided on the case-by-case basis; and a regularization mechanism should be complemented by new opportunities of legal migration.

Regularization has traditionally been conceived of as a state-level extraordinary policy. However, this article has shown that there are different supranational institutions which have continuously urged states to consider regularization for a certain group of irregular migrants. Their practices have paved the way for constructing an international regime of regularization, although this regime is at present rather thin. The EU Commission, by highlighting that the policy of regularization is not very 'extraordinary' for member states, has worked with scholars and defined the boundaries of an EU level regularization system. The Commission has adamantly promoted the norm of protection as an underlying principle of this system.

Regularization has also received important criticisms. However, this study has argued that, if defined by certain boundaries, regularization can become a useful policy for addressing the problems posed by irregular migration to the receiving states and societies. How it can become useful, and whether states will be willing to adopt regularization mechanisms for protection reasons, are questions that surely need further research. The emerging international regime of regularization and the role of EU Commission in it as a norm entrepreneur can attract more scholarly attention to the issue of regularization not only as a state-level policy, but also as a policy at supranational level.

\section{ACKNOWLEDGEMENTS}

The author wishes to thank Ken Booth and Alistair Shepherd for their comments and criticisms.

\section{NOTES}

1. For example, see the Telegraph's View, 26 April 2010. Available at http://www.telegraph.co.uk/news/politics/nick-clegg/7633466/Nick-Cleggs-amnesty-folly.html (accessed 17 July 2010)

2. During the research for this study, documents produced by the Commission and academic studies funded by the Commission were given a primary focus. This is because these documents, through their direct and indirect association with the Commission, can provide stronger and more realistic grounds for formulating an EU level regularization scheme.

3. Norm entrepreneurs try to persuade a reasonable number of states to embrace a new norm. The spread of norms in international regimes has three stages: norm emergence, norm cascade or broad acceptance of the norm, and internalization of norm (see Finnemore and Sikkink, 1998: 895). The Commission's norm of protection is still in the first stage, which is the norm emergence. Member states have not yet accepted the norm of protection.

4. See also EUROPOL Illegal Immigration Fact Sheet 2008. Available at http://www.europol.europa.eu/publications (accessed 17 July 2010).

5. For the details see EurActiv Website, Belgium to Legalise 25,000 Migrants, 20 July 2009. Available at: http://www.euractiv.com/en/socialeurope/belgium-legalise-25000-migrants/article-184257\# (accessed 17 July 2010).

6. EU decision-making in the area of migration is shared by the EU Commission, the Council (both the European Council consisting of heads of member states and the Council of Ministers). The Council is the body 
where member states act in the process of decision-making. The EU Parliament also has a joint decisionmaking power. In order to issue a regulation at EU level, three bodies should act together. In other words, supranational (the Commission and the European Parliament) and state-level (the Council) should interact to produce EU level policies. Since the Amsterdam Treaty, the decision-making procedure in the area of migration has been increasingly supranationalized. For general migration policy, see Geddes, 2008; for asylum policies see, Guild, 2006 and Lavanex, 2001.

7. The report can be obtained from the website: http://www.ulb.ac.be/assoc/odysseus/reguluk.html (accessed 17 July 2010).

8. There are also irregular migrants who cannot be returned because it is not possible to determine their countries of origin or their countries do not issue travel documents. It should be discussed whether a regularization mechanism for these types of irregular migrants is necessary or not. This is mainly because these migrants can be considered as 'stateless' and therefore, can be entitled to obtain protection based on humanitarian reasons. However, the Commission has not so far focused on this specific group. I'd like to thank the anonymous reviewer for reminding me of this point.

9. Interview with Jacques Barrot by Katherina Kloss, Member States are Compelled to Solidarity, 15 October 2008. Available at: http://www.cafebabel.com/eng/article/26812/interview-jacques-barrot-Migration-summit. html (accessed 17 July 2010).

\section{REFERENCES}

Adepoju, A., F. Van Noorloos, and A. Zoomers

2009 "Europe's Migration Agreements with Migrant-Sending Countries in the Global South: A Critical Review", International Migration, 48: 42-75.

Apap, J., P. De Bruycker, and C. Schmitter

2000 "Regularization of Illegal Migrants in the European Union: Summary Report of a Comparative Study", European Journal of Migration and Law, 2(34): 263-308.

Arango, J., and M. Jachimowicz

2005 "Regularizing Migrants in Spain: A New Approach”, Migration Information Source, http://www.migrationinformation.org/Feature/display.cfm?id=331(accessed 17 July 2010).

Baker, S.G.

1990 "The 'Amnesty’ Aftermath: Current Policy Issues Stemming from the Legalization Programs of the 1986 Migration Reform and Control Act”, International Migration Review, 31(1): 5-27.

Baldwin-Edwards, M. and A. Kraler

2009 "Regularizations in Europe: Study on Practices in the Area of Regularization of Illegally Staying Third-Country Nationals in the Member States of the EU", International Centre for Migration Policy Development, Vienna.

Bigo, D.

2004 "Criminalization of Migrants: the Side Effect of the Will to Control the Frontiers and the Sovereign Illusion”, In B. Bogusz, R. Cholewinski, A. Cygan and E. Szyszczak (Eds), Irregular Migration and Human Rights : Theoretical, European, and International Perspectives, Martinus Nijhoff Publishers, Leiden: 61-91.

Blaschke, J.

2008 Trends on Regularization of Third Country Nationals in Irregular Situation of Stay Across the European Union, European Parliament's Committee on Civil Liberties, Justice and Home Affairs, PE 393.282, January.

Boswell, C.

2002 "Addressing the Causes of Migratory and Refugee Movements: the Role of the European Union", The UNHCR New Issues in Refugee Research Working Paper, No: 73, December.

Bruggeman, W.

2002 Illegal Migration and Trafficking in Human Beings seen as a Security Problem for Europe, September, http://www.belgium.iom.int/STOPConference/Conference\%20Papers/20\%20Bruggeman\% 20Brussels\%20IOM.19.09.02.pdf (accessed 17 July 2010). 
Castles, S.

2004 "Confronting the Realities of Forced Migration", Migration Information Source, http://www.migrationinformation.org/feature/print.cfm?ID=222 (accessed 17 July 2010).

Commission of the European Communities

2000 Communication from the Commission to the Council and the European Parliament on A Community Migration Policy, COM(2000) 757 Final.

Commission of the European Communities

2001 Communication from the Commission to the Council and the European Parliament on a Common Policy on Illegal Migration, COM(2001) 672 Final.

Commission of the European Communities

2003 Communication from the Commission to the Council, the European Parliament, the European Economic and Social Committee, and the Committee of Regions on Migration, Integration and Employment, $\operatorname{COM}(2003) 336$ Final.

Commission of the European Communities

2004 Communication from the Commission to the Council, the European Parliament, the European Economic and Social Committee and the Committee of the Regions Study on the Links Between Legal and Illegal Migration, COM(2004) 412 Final.

Commission of the European Communities

2006 Communication from the Commission on Policy Priorities on the Fight against Illegal Migration of Third-Country Nationals, $\operatorname{COM}(2006) 402$ Final.

Commission of the European Communities

2008 A Common Migration Policy for Europe: Principles, Actions and Tools, COM(2008) 359 Final.

Council of Europe

2007a Parliamentary Assembly, Recommendation 1807 Regularization Programmes for Irregular Migrants, http://assembly.coe.int/Mainf.asp?link=/Documents/AdoptedText/ta07/EREC1807.htm (accessed 17 July 2010).

Council of Europe

2007b Parliamentary Assembly, Resolution 1568 Regularization Programmes for Irregular Migrants.

DeWind, J.

2007 "Response to Hathaway", Journal of Refugee Studies, 20(3): 381-85.

Fargues, P.

2009 "Work, Refuge, Transit: An Emerging Pattern of Irregular Migration South and East of the Mediterranean”, International Migration Review, 43(3): 544-577.

Finnemore, M. and K. Sikkink

1998 "International Norm Dynamics and Political Change”, International Organization, 52(4): 887-917.

Gammeltoft-Hansen, T.

2007 The Extraterritorializiation of Asylum and the Advent of 'Protection Lite', Danish Institute for International Studies, Copenhagen.

Geddes, A.

2008 Immigration and European Integration: Beyond Fortress Europe, Manchester University Press, Manchester.

Ghosh, B.

1998 Huddled Masses and Uncertain Shores: Insights into Irregular Migration, The Martinues Nijhoff Publishers, Hague/Boston/London.

Global Commission of International Migration

2005 Migration in an Interconnected World: New Directions for Action, http://www.gcim.org/attachements/gcim-complete-report-2005.pdf (accessed 17 July 2010).

Guild, E.

2006 “The Europeanization of Europe's Asylum Policy”, International Journal of Refugee Law, 18(3-4): 630-651.

Lavanex, S.

2001 Europeanization of Refugee Policies, Ashgate, Aldershot. 
Levinson, A.

2005a The Regularization of Unauthorized Migrants: Literature Survey and Country Case Studies, University of Oxford Centre on Migration, Policy and Society, Oxford.

2005b Why Countries Continue to Consider Regularization, Migration Information Source, http://www.migrationinformation.org/Feature/display.cfm?ID=330 (accessed 17 July 2010).

Lutterbeck, D.

2006 "Policing Migration in the Mediterranean", Mediterranean Politics, 11(1): 59-82.

Martin, S. F.

2000 "Forced Migration and the Evolving Humanitarian Regime", The UNHCR EPUA Working Papers, 20, July.

McNevin, A.

2006 "Political Belonging in a Neoliberal Era: The Struggle of the Sans-Papiers", Citizenship Studies, 10 (2): 135-151.

Morrison, J., and B. Crosland

2001 "The Trafficking and Smuggling of Refugees: the End Game in European Asylum Policy?", The UNHCR New Issues in Refugee Research Working Paper Series, 39.

Organization for Economic and Cooperation and Development Secretariat

2000 "Some Lessons from Regularization Programs", in Combating Irregular Employment of Foreign Workers, OECD Publishing, Paris: 53-66.

Papademetriou, D.G.

2005 "The Regularization Option in Managing İregular Migration More Effectively: A Comparative Perspective", Migration Policy Institute Policy Paper, 4.

Papadopoulou, A.

2005 "Regularization Programmes: An Effective Instrument of Migration Policy?", Global Commission of International Migration, 33, May.

Papantoniou-Grangouli, M. and K.M. Leventi

2000 "The Legalization of Aliens in Greece", International Migration Review, 34(3): 950-955.

Schmeidl, S.

1997 "Exploring the Causes of Forced Migration: A Pooled Time-Series Analysis 1971-1990", Social Science Quarterly, 78(2): 284-308.

Spijkerboer, T.

2007 "The Human Costs of Border Control", European Journal of Migration and Law, 9: 127-139.

The German Marshall Fund of the United States, The Lynde and Harry Bradley Foundation, Compagnia di Sao Paolo, Barrow Cadbury Trust, Transatlantic Trends: Migration 2008, www.transatlantictrends. org (accessed 17 July 2010). Thym, D.

2008 "Respect for Private and Family Life Under Article 8 ECHR In Migration Cases: A Human Right to Regularize İregular Stay?", International and Comparative Law Quarterly, 57(2): 87-112.

Turton, D.

2003 “Conceptualizing Forced Migration”, Refugee Studies Centre Working Paper No. 12, University of Oxford, Oxford.

United Nations Office on Drugs and Crime

2006 Organized Crime and Irregular Migration from Africa to Europe, UN, Vienna. 